\title{
11
}

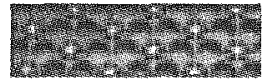

\section{Securities market development: assessing and improving market efficiency}

\author{
Michael Hasenstab
}

In 1978, China began a financial reform process that continues to grow in extent and impact, reducing the role of direct government credit allocation in favour of a market-driven allocation system (Table 11.1). While still in their infancy, these markets are providing an important means of channeling savings into productive economic uses. Under this new system, China's securities markets take on an increasingly important role and within this framework foreign financial institutions have the opportunity to hasten the development of domestic financial markets and improve efficiency in the allocation of capital.

These reforms have laid the initial groundwork for the development of securities markets in China and the effects of such reform on the recent growth of China's tradable securities markets is well summarised by Hale (2002).

The number of listed companies has grown from 14 to nearly 1100. Market capitalisation now exceeds US $\$ 525$ billion or a sum just over 50 per cent of GDP compared to numbers in the 20-60 per cent range for many developing countries. China also has developed markets for treasury bonds and corporate bonds. In 1999, the T-bond market was worth 401 billion Yuan (US $\$ 48.4$ billion). The corporate bond market is much less developed. At the end of 1999, there were only 10 listed bonds with a market value of 50 billion Yuan (US $\$ 6$ billion). But bond issuance during 1999 rose to 20 billion Yuan (US\$2.4 billion), so there is potential for the market to expand more rapidly in response to both institutional and retail investor demand.

By March 2001, China's daily stockmarket turnover reached 25 trillion yuan, or 3 trillion US dollars (China People's Daily 2001). 


\section{TABLE11.1 CHRONOLOGY OF KEY FINANCIAL MARKET REFORMS}

\section{Perioda}

1978-84

Key reforms

1. Agricultural reform: creation of the Agricultural Bank, emergence of Town and Village Enterprises (locally funded) and formation of rural credit cooperatives.

2. Unofficial operation of inter-bank market among east coast banks.

3. Ministry of Finance (MOF) issues treasury bonds to finance the central government deficit.

4. People's Bank of China (PBC) allows select companies to issue share certificates on a very limited basis and undertake trial profit-sharing schemes in select firms.

5. PBC and MOF officially separated.

6. Trust and Invesiment Companies (TICs) and urban credit cooperatives permitted.

7. Foreign banks permitted to open representative offices.

1985-88 1. Emergence of a money market and secondary market in certificates of deposit (CDs).

2. Local bank branches allowed to take in local deposits and no longer receive full funding from head offices.

3. Industrial Commercial Bank of China Shanghai branch issues the first financial bond.

4. Inter-bank market formalised in 55 major cities.

5. TICs expand in number and in total assets under management.

6. PBC transfers commercial banking operations to Industrial and Commercial Bank of China.

1989-91 1. Shanghal and Shenzhen Securities Exchanges opened. Domestic and foreign share ownership segmented between $A$ and $B$ shares, respectively.

2. Banks and financial institutions begin underwriting bonds.

1992-95 1. Three new policy banks (State Development Bank, Agricultural Development Bank and Export-Import

\section{Major implications}

China begins to dismantle administrative economic controls and sets the groundwork for the development of a market and increasingly private economy. The use of treasury bond issuance to finance the fiscal deficit creates the need for a formal treasurybond market in the future. Increased reliance on this market will later force the government to allow market pricing of debt and secondary trading. PBC begins first stage in what will prove to be a very long process in establishing a real central bank able to implement independent monetary policy, an object still unattained by the end of the century.

Intormal markets emerge to take the place of previously governmentcontrolled means of capital allocation. The growth of such markets and institutions will later force the government to formalise such markets. Financial sector becomes increasingly dependent on market forces.

Securities markets are increasingly standardised and the level of sophistication in capital markets increases.

Framework established for the separation of commercial and policy bank lending. Elimination of the 
Period ${ }^{a}$

Key reforms

Bank) created.

2. PBC stops direct lending to MOF.

3. Elimination of two-currency system as

Foreign Exchange Certificates (FEC) are

converted into renminbi (local currency).

1996-99 1. Foreign banks permitted to engage in renminbibusiness, and on a limited scale, trade local bonds.

2. Reorganisation of $\mathrm{PBC}$ into nine regional centres.

3. New securities regulations (Article 214) passed by central government.

4. Inter-bank market centralised out of Shanghai.

5. Banks prohibited from secondary trading of government bonds in Shanghai.

6. Overseas share listing of domestic firms and issuance of global sovereign bonds.

7. Current account liberalisation.

8. Collapse of Guandong International

Trust and Investment Company (GITIC).

9. MOF places first of several global bonds in international capital markets.

2000-01 1. Establishment of personal credit system in Shanghai on 1 July 2000.

2. Adoption of WTO-consistent laws and abolition of outdated and WTO-

inconsistent laws and regulations (to date, 6 batches of such laws have been abolished and more are underreview).

3. 2001-05 five-year plan calls for swift development of the service sector (including banking and insurance).

\section{Major implications}

two-currency system is a crucial step toward greater internationalisation of the Chinese financial system.

Equity issuance in local and global markets increases. Securities markets take on an increasingly important means of fund raising while the GITIC bankruptcy motivates overhaul of securities and issuance regulation. Reform of PBC and inter-bank market helps set groundwork that will allow the $\mathrm{PBC}$ to manage monetary policy better in the future. Trading volume of secondary government bonds in Shanghai decreases late in this period. Overseas share and debt issuance and foreign participation in domestic banking increases Chinese financial internationalisation.

Continued financial market deepening at the consumer level. New laws to make China WTO-compliant are moving China to allow increased access by foreign financial institutions to provide expanded commercial and retail foreign exchange and renminbi, fund management, and insurance services.

Note: aPeriod divisions from 1978-91 are taken from Xu (1998).

Source: Author's compilation.

While the increased size of China's securities highlights the elevated role of these markets in the allocation of capital, questions remain over the efficiency of such markets. This chapter will first outline the importance of efficiently operating securities markets for China. Second it will discuss empirical tests of the efficiency of these markets. Finally, it will assess policy reform efforts to date and suggest possible future policy innovations to further improve the efficiency of China's securities markets. 


\section{THE ROLE OF FINANCIAL MARKETS IN CHINA}

More efficient securities markets will allow the government to finance its fiscal deficit more efficiently and for companies to raise much-needed finance. Properly functioning government bond markets are also important for the central bank's execution of monetary policy through open market operations. A well developed and well functioning government bond market also provides the capital market with information on sovereign risk, inflation and interest rate expectations, a benchmark for pricing new corporate debt issues in global markets, and efficient pricing of new government bond issues to minimise government financing costs.

Conversely, inefficient or dysfunctional markets threaten to raise government and company capital financing costs, misallocate capital to low productivity uses, and misprice sovereign and corporate risk. At the aggregate level, the close and positive link between the scale and depth of the financial sector and overall macroeconomic performance means that poorly functioning securities markets would be likely to seriously inhibit China's economic growth.

As China moves towards capital account liberalisation, the efficiency of China's securities markets is of paramount importance. Inefficient domestic capital markets do not allocate capital inflows to the most efficient uses and inflows with an open capital account, could create large-scale price disequilibria which would adversely affect government and company fundraising efforts and direct capital to inefficient sectors of the economy.

\section{EVALUATION OF EQUITY AND DEBT MARKET BEHAVIOUR}

While the size of securities markets has grown, questions remain over the efficiency of such markets. Hasenstab (2001) tested several components of market efficiency in debt and equity markets to help evaluate China's securities markets, which in turn can help assess China's readiness to open its capital account. Tests show that domestically-traded stocks and bonds are a random walk process which implies that they are efficient; at times an underlying common trend is present across various benchmark bond yields, creating a yield curve; and the yield curve has often reflected expectations of falling rates with a short end yield curve inversion.

Conversely, the equities markets show characteristics of market inefficiency and underdevelopment in several instances; the secondary bond market does not 
behave as a cointegrated system in periods of low trading volume; and the expectations hypothesis has extremely weak predictive power in the bond market. Such empirical analysis suggests that these markets lack the level of efficiency and development required to deal with the large foreign capital inflows likely to accompany full capital account convertibility.

China has control over the timetable of its formal and official movement to capital account convertibility, but there are already instances of integration between China's domestic and international equity markets, despite official segmentation. The presence of integration in the equities market, despite official controls to segment the domestic market from the international market, indicates that China's integration with global capital markets is moving ahead. With China increasingly dependent on additional sources of finance, this global integration is not contrary to Chinese interests, but China faces a time constraint. With integration developing on its own, the onus is on China to improve the efficiency of its domestic markets to prevent instability emerging from widespread integration without the support of domestic market efficiency.

\section{Debt markets}

In line with behaviour witnessed in developed markets, Hasenstab (2001) finds that the behaviour of domestic bond yields in this market imply efficiency. Furthermore, cointegration testing indicates that there is an underlying trend between the various benchmark yields, justifying the claim that China has a 'yield curve'. Error correction tests regarding the relationship between different parts of the curve were far less conclusive. The expectations hypothesis on the term structure of interest rates proved to have low predictive powers in China. It appears that the bond market behaves differently over different periods and is segmented between benchmark bonds with varying maturities.

The answer to the question 'is China's bond market sufficiently developed to operate with open capital controls?', is 'not yet'. When the government promoted secondary market activity on the Shanghai exchange before 1999, the market operated with an underlying common trend; that is, there was a yield curve and the outlook for the ongoing development and deepening of this market appeared optimistic. Budding characteristics of a more developed bond market should have been nurtured. Instead, reductions in institutional participation limits in this market reduced trading volume and reversed these trends. Without a liquid and transparent 


\section{TABLE 11.2 EVALUATION OF CHINA'S SECURITIES MARKETS}

\author{
Requirements a \\ Standardised contracts
}

Grading of risk via underwriting

Database of historic statistics

Standardisation of applicable laws

Standardisation of service quality

Technology to handle complexity analysis

\section{Evaluation of progress in China}

Centralisation of trading markets to Shanghai and Shenzhen has helped significantly and numerous efforts to standardise the treatment of cash and pay-in-kind dividends to various classes of shareholder have improved overall standardisation. On the other hand, multiple share markets and multiple classes of equity holder greatly inhibit progress. Credit claims on assets are still unclear.

Essentially non-existent. The government still controls the listing process. A lack of independent investment banks or private banks hinders this process. More foreign bank underwriting activity would greatly improve this situation and transfer the necessary technology and skills to domestic market participants. Increased capabilities of new rating agencies could help provide some level of risk grading.

Greatly improved in the past few years. Historic prices for most equities-listed domestically and internationally-are readily available. Comprehensive government bond price data are far more difficult to obtain. Inter-bank data is not publicly available-even to domestic financial players. Furthermore, many corporate bonds are traded over the counter without publicly available prices.

Securities laws are often 'on the books' as mandated in the 1998 Securities Reform Act, but few are enforced. Ownership remains unclear and the lack of clear bankruptcy laws inhibits credit restructuring-see, for example, the Guandong Enterprises (GDE) and GITIC cases.

Weak but gradually improving. Newly-gained experience in debt work-outs will help in the future if standardised measures can be built from the process.

Arguably better in China than most developing countries. of The Shanghai Stock Exchange is nearly fully automated and the trading floor provides more of a public relations showcase than an actual market function. There are concerns about the oversight of the systems responsible for settlement and clearing of trades. Analyst skill levels in domestic Chinese financial institutions are improving dramatically. Foreign participation in the market will help facilitate 'technology skills transfers'.

Notes: ${ }^{T}$ The China Chengxin Credit Rating Company, which is the newest joint venture rating agency in China, is an example.

Source: Author's compilation. 
secondary government bond market that trades as a 'yield curve', China lacks a necessary building block towards developing an efficient securities market.

In addition to the domestic bond market, China issues global government bonds on the international market. These parallel markets are officially segmented by China's capital control restrictions regarding Chinese ownership of financial assets issued in foreign markets. Tests by Hasenstab (2001) of domestic and global relationships of Chinese government bonds confirmed that these two markets are completely segmented; that is, capital market controls are complete and effective for the time being. There are several explanations as to why these two markets have remained segmented. They include official capital controls, the small total amount of Chinese global bonds on issue, the lack of significant profit incentives for investors to circumvent capital controls, the institutional nature of bond ownership making illegal circumvention of capital controls very difficult, and suspected intervention by Chinese government-directed financial institutions with offshore investment capacities to hold up the value of China's global bonds in periods of global financial turmoil.

\section{Equity markets}

While similar capital controls affecting the parallel global and domestic bond markets apply to parallel domestic and international Chinese equity markets, the greater total issuance size, the higher potential profits from circumvention of capital controls, and the diverse ownership of both institutions and individuals create a significantly different market environment.

Extending empirical testing of debt market global integration to the equity markets and building upon the growing literature on Chinese stockmarket behaviour and efficiency, Hasenstab (2001) explored the relationship between mainland Chinese and Hong Kong equity markets. Econometric analysis of individual stock returns of Chinese companies dually listed in the Hong Kong $\mathrm{H}$ share and mainland Chinese $\mathrm{A}$ share markets, finds evidence, not yet reported in the literature, of both partial integration between these two markets and a significant uni-directional price effect going from the Hong Kong to the Chinese equity markets for some of the sample's dually listed companies. This evidence of partial integration in over 50 per cent of dually listed stocks is in direct contrast to observation of the segmentation of the Chinese bond market. Furthermore, tests confirm that the stock prices are first difference stationary, an important indicator of random walk behaviour.

The operation of parallel but officially-separated markets trading securities written 
on the same underlying companies also allowed the testing of the efficient market hypothesis. Error correction modelling identified a significant number of cases of unidirectional price transmission relationships from the Hong Kong market to the mainland Chinese market that violate this hypothesis. If China were to open its capital accounts while its markets remained inefficient, there could be inefficiencies in the allocation of capital if market efficiency dynamics identified in this sample apply to China's capital markets in general.

\section{EVALUATION OF CHINA'S SECURITIES MARKET REFORM}

While China has moved a long way towards building securities markets, concerted policy reforms must continue in order to complete this process. An evaluation of China's securities market reform effort is summarised in Table 11.2. The left-hand column outlines some of the basic requirements for the successful development of China's securities market. China's progress towards meeting these requirements is then assessed in the right-hand column.

\section{Policy innovations}

China's future economic success and stability will rest largely on the ability of the PBS and the MOF to continue their proactive reforms and to mobilise capital to fund the real economy better through a private, market-driven financial sector. The stateowned sector will also increasingly rely on private capital markets to fund its recapitalisation efforts. The following are possible policy initiatives that could help develop such markets.

- Delay capital account convertibility until both the bond and equity markets trade efficiently; that is, until the efficient market hypothesis is broadly satisfied. Until internationally and domestically-listed Chinese government bond and equities trade efficiently, full capital account convertibility risks allowing initial capital to flow into an inefficient domestic Chinese market and thus exacerbate price disequilibria. This would direct capital to low efficiency uses.

- Open the domestic market to foreign banking and securities firms and permit these firms to source yuan funds from domestic institutions and investors and allow them to invest in domestic assets. Despite the growth in tradable securities markets, Hale (2002) estimates that the ten officially licensed fund-management companies control only US $\$ 6.8$ billion spread across 33 closed-end mutual funds. To expand the share of mutual fund assets, China 
has recently begun to introduce open-ended funds. There are currently six joint ventures between Chinese and foreign asset managers; however, joint venture regulations requiring foreign asset mangers to partner with local firms will limit the growth of the asset management industry in China. Furthermore, Hale (2002) reports that foreign banks only have a 1 per cent market share in China and are constrained by geographic barriers to expansion. Foreign firms will bring competitive bidding and risk valuations to the domestic market to determine real prices. Prices that fully reflect risk are a critical information component missing from the Chinese market at present and the longer prices remain distorted, the greater the potential for asset bubbles. These firms will help facilitate financial services technology and skill transfers and create future distribution links to foreign client markets for future placement of Chinese securities. Japanese and Latin American historical examples suggest that allowing domestic banks to compete directly in deposit-taking activity will not lead to the immediate collapse of Chinese firms. The development of an advanced domestic capital market necessary to finance future government spending and assist in the recapitalisation of the state sector will take considerably longer in isolation.

- Regularised and standardised government debt issuance. Forced debt issuance only perpetrates circular debt (or triangle debt) and marginalises the legitimacy of the government bond markets as real institutions for long-term fund raising. Developing a regular auction timetable, pre-announcing volumes, issuing standardised treasuries available to multiple classes of investor, and pricing these instruments via public bidding would allow China to develop a deep and liquid bond market while minimising speculative behaviour. This developed government bond market would give real prices to government debt serving as an important feedback mechanism for government policy, providing a real benchmark for pricing other fixed income instruments. It would allow for better risk management through standard risk management hedging techniques and help end the ongoing cycle of non-transparent circular debt finance between the government, state banks and the state-owned sector. Ultimately government debt financing costs will be lowered by reducing market uncertainty.

- Current efforts to move government bond trading away from the Shanghai exchange to the inter-bank market should be stopped and a unified treasury bond market should be promoted. Given the lack of transparency of bond trading in the inter-bank market and the fact that the secondary spot 
market on the Shanghai exchange exhibits a number of signs of behaving in an efficient form, this efficient trading arena should be capitalised on and trading activity should be returned to the Shanghai exchange.

The periods in which secondary government bond trading volume on the Shanghai exchange is highest correlates to periods when the presence of a yield curve is indicated by statistical testing of this market. If the market were massively inefficient, it would make more sense to correct the trading rules and regulations before increasing issuance. It appears, however, that given sufficient volume, the secondary bond market exhibits several important characteristics of market efficiency. Obviously rules and regulations need to be improved, but this longer-term reform requirement should not impede the continued operation of Shanghai treasury bond trading. If the government follows through with its intention to move all trading activity to the inter-bank market, every effort to create an open and transparent market must be made.

- Increase stock and bond issuance to effect changes in corporate governance. Bottlenecks in the approval process for share issuance continue to hamper market development. The current rate of domestic company listings averages 8.5 per month. At this rate it will take approximately two years to deal with the current backlog of companies that have registered an interest to list in 1999 (Neoh 2000). Furthermore, the quota issuance system, whereby local governments nominate which companies are permitted to list, takes the decision away from the market and puts it into the hands of administrators. Without an active underwriter market, the veil of secrecy is perpetuated and lack of transparency creates information asymmetry problems that raise overall market risk levels. Neoh (2000) observes that local governments tend to put forward for listing companies in which they have an equity stake. Expanding total issuance through changes to the underwriting system is a first step.

While continued stock issuance and thus the transfer of ownership rights could dramatically change corporate governance in both state-owned and non-stateowned companies, the state's dominance in tradable and non-tradable shares has largely prevented the development of a new political economy in corporate ownership. On the one hand, ongoing issuance of cash dividends to state holders and share dividends or rights offerings to non-state equity holders has helped decrease the state's once unequivocal majority ownership stake in listed firms. On the other hand, even new stock issuance does not necessarily change 
corporate governance. Xu and Wang (1997) found official managers and party officials hold key board and supervisory positions in many incorporated firms with high levels of state ownership. Therefore, the ongoing issuance of shares in conjunction with the issuance of shares to non-state investors and the deemphasis on government-appointed managers will increasingly empower shareholders to place pressure on firms to maximise corporate profits.

- Total corporate bond issuance needs to increase to close the gap with total equity issuance so as to prevent an unbalanced capital market and provide firms with longer-term debt finance options. Secondary markets need to be promoted in corporate bonds to allow the market to find real prices and limit the liquidity premium required by voluntary investors to hold such corporate securities. Furthermore, both issuance markets-but especially the corporate debt issuance market-need to be based more on objective financial criteria and to be subject to less political influence.

- Utilise the Hong Kong market. China is the only developing country that has a developed financial market within its borders, namely Hong Kong. Given Hong Kong's possible importance in facilitating price discovery superior to mainland markets, increased use of the Hong Kong markets for future funding needs until the mainland Chinese markets are more developed could facilitate more efficient fund raising. If the results found in the data reported in this chapter are true for the broader market, Hong Kong's better price discovery could help lower information asymmetry problems and thus lower the risk premium placed on Chinese securities. A lower risk premium will thus lower the price at which companies can raise capital through share issuance. Recent proposals to issue Chinese treasury government bonds via the Hong Kong Stock Exchange should indicate some willingness and interest by Chinese central government officials to capitalise on Hong Kong's existing financial market infrastructure, and further pursuit of such efforts would complement the domestic development of mainland exchanges.

- Invest heavily in technical trading systems and vigilantly continue to upgrade financial reporting standards and legal rights of share and bondholders. The lack of a simultaneous payments system, the lack of a corporate bond repo market, inefficient settlement systems, and the lack of unified real time price sources will dramatically hinder the development of both corporate and government securities markets. China has been upgrading its trading sys- 
tems rapidly but additional investments are needed to keep pace with the increasing volume of total debt and equity issuance as well as to expand the scope of distribution.

Without full financial disclosure, proper enforcement of market regulations and an extension of Article 214 to the bond and derivatives markets, the mechanism for shareholders to exert positive changes on corporate governance will be marginalised, poor firm investment decisions will go unchecked, and insider trading will dominate the exchanges.

While the challenges of future reform remain great, few countries have moved so far in the development of tradable securities markets in such a short period as has China. Hopefully the issues raised in this chapter can be of use in continuing to build and reform what will be, later in this century alongside the United States and the Euro block, one of the world's three most important capital markets.

\section{Notes}

1 These build upon the policy recommendations of Hasenstab (1999). 